This article was downloaded by: [University College Falmouth ]

On: 23 October 2014, At: 07:13

Publisher: Routledge

Informa Ltd Registered in England and Wales Registered Number: 1072954 Registered office: Mortimer House, 37-41 Mortimer Street, London W1T 3J H, UK

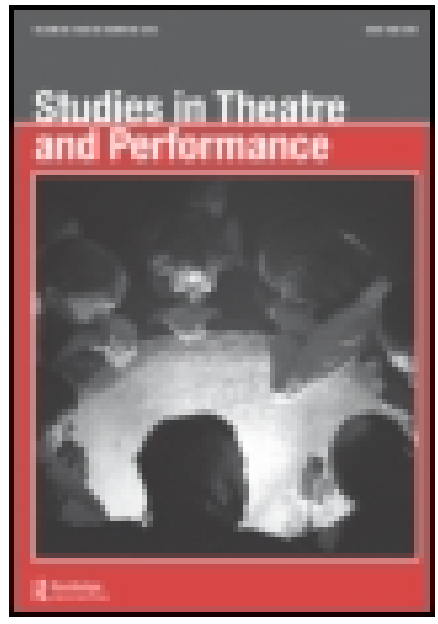

\title{
Studies in Theatre and Performance
}

Publication details, including instructions for authors and subscription information:

http:// www.tandfonline.com/loi/rstp20

\section{'Iam a Poor, Skinny Man': Persona and physicality in the work of Karl Valentin}

Oliver Double \& Michael Wilson

Published online: 03 J an 2014.

To cite this article: Oliver Double \& Michael Wilson (2008) 'Iam a Poor, Skinny Man': Persona and physicality in the work of Karl Valentin, Studies in Theatre and Performance, 28:3, 213-221

To link to this article: http:// dx.doi.org/ 10.1386/stap.28.3.213_1

\section{PLEASE SCROLL DOWN FOR ARTICLE}

Taylor \& Francis makes every effort to ensure the accuracy of all the information (the "Content") contained in the publications on our platform. However, Taylor \& Francis, our agents, and our licensors make no representations or warranties whatsoever as to the accuracy, completeness, or suitability for any purpose of the Content. Any opinions and views expressed in this publication are the opinions and views of the authors, and are not the views of or endorsed by Taylor \& Francis. The accuracy of the Content should not be relied upon and should be independently verified with primary sources of information. Taylor and Francis shall not be liable for any losses, actions, claims, proceedings, demands, costs, expenses, damages, and other liabilities whatsoever or howsoever caused arising directly or indirectly in connection with, in relation to or arising out of the use of the Content.

This article may be used for research, teaching, and private study purposes. Any substantial or systematic reproduction, redistribution, reselling, loan, sub-licensing, systematic supply, or distribution in any form to anyone is expressly forbidden. Terms \& Conditions of access and use can be found at http://www.tandfonline.com/page/terms-and-conditions 


\section{'I am a Poor, Skinny Man': Persona and physicality in the work of Karl Valentin}

\section{Oliver Double and Michael Wilson}

\section{Keywords}

Brecht

stand-up comedy

cabaret

German theatre

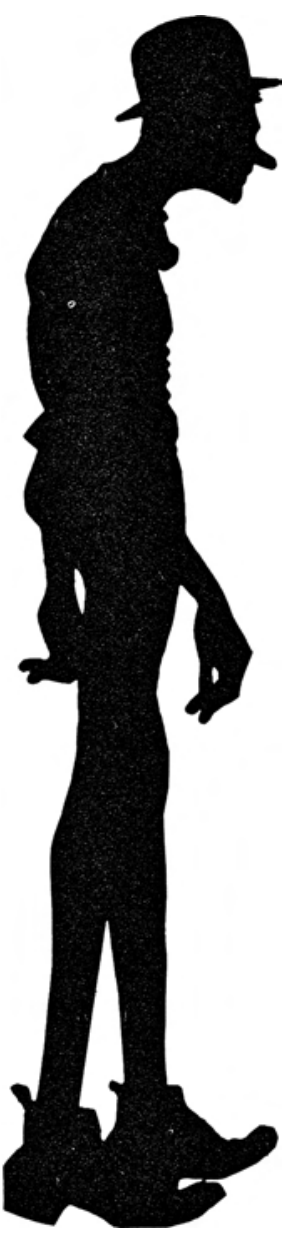

Figure 1: The Silhouette of Valentin.

\begin{abstract}
The celebrated Munich cabaret artist Karl Valentin first came to prominence with his performance of his sketch Das Aquarium in 1908. This was also the moment at which he first established a comedy based upon extreme logic, wordplay and verbal misunderstanding, which in turn created a world in which his innocent 'matter-of-fact-ness' exposed the absurdities of social situations. This article explores Valentin's use of his extraordinary skinniness to create both an effective comic persona and a comic physicality in his work. The authors argue that it was in Valentin's slightly earlier sketch, Ich bin ein armer magerer Mann, that the comedian found his physical 'comic voice', and they go on to provide an analysis of the importance of physicality in Valentin's work, particularly in relation to this sketch. A new translation of the sketch is also provided.
\end{abstract}

\section{Karl Valentin}

Six years passed between Karl Valentin's attendance at the Varietéschule in Nürnberg and his first steps onto the professional stage in 1902, at the age of twenty, and his unexpected success as a 'Nachständler', or 'floorspot' at the Baderwirt in Munich with his monologue Das Aquarium (The Aquarium). For the following three decades Valentin, working (from 1913) primarily with his stage partner Elisabeth Wellano, known as Liesl Karlstadt, became the most successful comedian on stage, film and the airwaves in all of Germany. During the war he sank into relative obscurity, and died in 1948, whilst on a career-reviving tour with Karlstadt.

Amongst theatre scholars Valentin is perhaps best known for his collaborations with Bertolt Brecht in Munich in the early 1920s (most notably Der rote Zibebe, a cabaret staged at the Kammerspiele in September 1922, premiering his playlet Das Christbaumbrettl, and the film Mysterien eines Friseursalons in early 1923) and the influence he exerted on the young playwright and poet:

... the man he learnt most from was the clown Valentin, who performed in a beer-hall. He did short sketches in which he played refractory employees, orchestral musicians or photographers, who hated their employer and made him look ridiculous. (Brecht 1965: 69).

Brecht 'never forgot Valentin, nor the debt he owed him' (Ewen 1970: 65) and he likened their relationship to that of Eisler and Schoenberg - Eisler 
had studied under Schoenberg and was heavily influenced by him (Hayman 1983: 49).

Valentin was born Valentin Ludwig Fey on 4 June 1882 in the Munich suburb of $\mathrm{Au}$ and, after finishing school, completed three years' apprenticeship as a carpenter, before starting his stage career as a Salonhumorist in the style of his hero Max Karlstadt (in whose honour both Valentin and Liesl Karlstadt adopted their stage names). It was something of a false start for Valentin: after studying in Nürnberg for three months under the comedian Hermann Strebel, he secured his first engagement at Varieté Zeughaus only to discover that Strebel had stolen his material and performed it there the week before. Valentin's career suffered a further setback when his father died suddenly and he was obliged to return to Munich to run the family business with his mother.

For the next four years Valentin curbed his stage ambitions whilst performing the role of the small businessman in Munich, in his spare time employing his carpentry skills by building a multi-instrumental music machine, which he called the

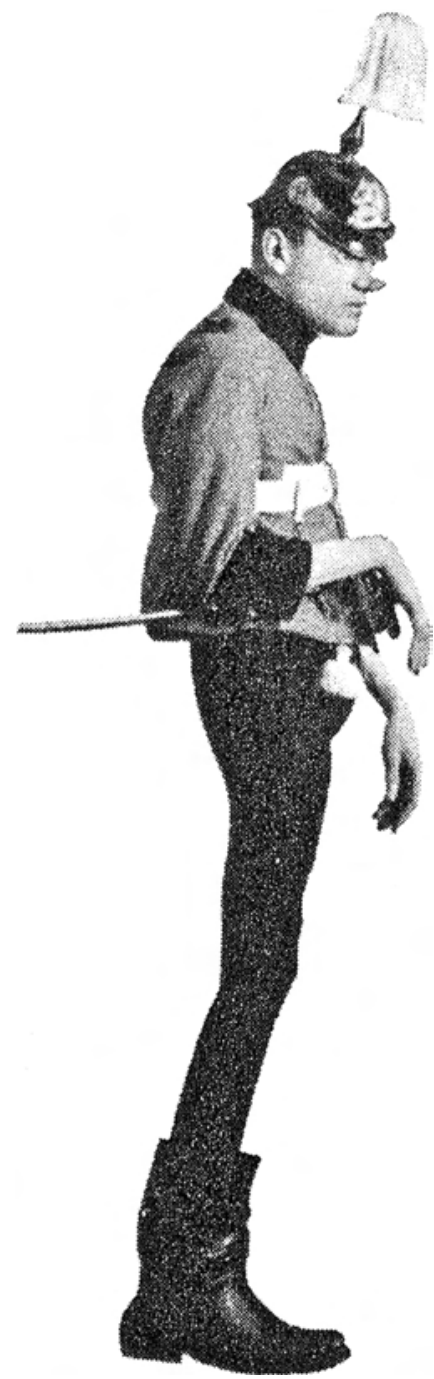

Figure 2: Valentin in role as a soldier on guard duty.

'Orchestrion'. By 1906 Valentin's lack of enthusiasm for business was having an effect on the family's financial security, so the business was sold and Valentin set off to tour with his Orchestrion under the persona of 'Charles Fey - Musical-Fantast' in February 1907.

The venture was a disaster - the Orchestrion was cumbersome and expensive to transport, for a start - and before long Valentin had to pawn his machine in order to afford the fare back to Munich. Penniless and with a young family to support, he took lodgings with Ludwig Greiner and his wife, and at this point his luck began to change. Changing his name once more, this time to Karl Valentin, he began performing monologues and humorous rhyming couplets, still very much in the style of a Salonhumorist, as a Nachständler at the Baderwirt - performing for free at the end of the evening once all the advertised entertainment had finished. 


\section{Ich bin ein armer, magerer Mann}

It is often assumed that it was his 1908 sketch Das Aquarium that sealed Valentin's success and, whilst it is true that it was this sketch that made his name and secured him a contract with Josef Durner at the well-established Frankfurter Hof, it was the slightly earlier sketch, Ich bin ein armer, magerer Mann, that enabled Valentin to initially 'find his voice' as a performer. Das Aquarium was the sketch in which he established the device of creating social confusion and mayhem through the literal interpretation of language - a kind of logic in extremis - that later came to be seen as one of the trademark features of Valentin's comic style, but the other defining characteristic of his comedic identity - the exploitation of his physical appearance - can be traced back to the earlier monologue.

The story goes that it was Greiner who persuaded Valentin to first abandon the dinner suit of the Salonhumorist and concentrate on featuring his own physical peculiarity (Valentin was not only uncommonly thin and gangly, he also had bright orange hair - an unusual sight on the streets of Munich in the early 1900s), but there were others who also played their part. According to Valentin's daughter Bertl Valentin, it was Greiner's wife who found an old athletics kit in the attic and took her scissors and needle and thread to it in order to make the aspiring comedian a costume that accentuated his physique (Valentin 1971: 27). Also Valentin himself needed no persuading. Throughout his childhood and adolescence he had become fascinated by the physical attributes of the street performers, eccentrics and local characters who populated Au. One such 'Originaler' was 'Benimelber', who 'weighed three and a half hundred weight without his clothes and had to have a special coffin of huge dimensions made when he died' (Schulte 1982: 15). This early interest in physical peculiarity shows itself time and again in Valentin's preference for juxtaposing contrasting physicalities in his work - his own physique with that of the short, dumpy Karlstadt, and the use of giants and dwarves as extras in his sketches and playlets. According to Bertl, Greiner's suggestion sent her father rushing straight back to his room where he wrote Ich bin ein armer, magerer Mann (Valentin 1971: 27). It was performed at the Baderwirt by Valentin under the stage name Skeletgiggerl (Skeleton-chuckle). Interestingly, the word 'Gigerl' (with one 'g') is a Bavarian/Austrian word for a dandy. Clearly, Valentin here is using a pun, and an ironic one at that, as his obvious poverty and ill-fitting costume suggest that he is anything but a dandy. Once again this kind of use of language was set to become a feature of so much of his work.

\section{'I am a Poor Skinny Man', Karl Valentin, (translated by Michael Wilson and Oliver Double)}

Oh, it's certainly such a terrible thing

When a fellow's as thin as a piece of string

Perhaps I shouldn't really moan

But I'm as thin as a chicken bone. 
What must I have done wrong to have been treated so badly by Mother Nature? I just don't understand it. The problem can't lie in the family, because my father tips the scales at three hundred weight, my mother at over seventeen stone and my sister's married to a navvy. And still I end up being so skinny. Well, I'm bad enough now, but you should have seen me when I was younger. When I was born, I looked like a pepperoni. When I was a baby, there was no need for a cradle - my mother simply shoved me into a cigar tube and rolled me around the table, I was so skinny.

But even so, my father is proud of me. He doesn't like fat children, and that's why he thinks I'm such a fine fellow - because I'm such a fine fellow. He says I'll start carrying more weight if I get a job as a porter. Once I was in a coffee shop and was leaning against the billiard table and, because I'm so skinny, somebody thought I was the cue.

But the greatest mischief was when I had to go for my army medical they took one look at me and almost did themselves a mischief. And then, when I got undressed all my ribs stuck out - my mother used to use me to grate the horseradish - but anyway, when they saw me, they said, 'You look like a sheet of corrugated iron.' However, because I'm built this way they wouldn't take me. The army still can't find a use for me.

Of course, I'm also terribly light. For example, if I go to a restaurant and the waiter turns on the extractor fan, I have to tie myself to the table so I don't get sucked up into the duct. Then once someone said to me, 'You're such a freak, you could sell your body for anatomy.' So I went to see the Professor of Anatomy and offered myself up to him and he said, 'How much would you charge?' and I said, 'I couldn't possibly hand myself over for less than eighty pounds.' 'Eighty pounds?' said the Professor, 'How did you work out that you're worth eighty pounds?' 'Simple', I said, 'the other day I took off my clothes and weighed myself on the scales. And it read eighty pounds.'

Then one time I read about this crematorium, and I thought, that's the place you go to if you want to be burned, once you've died. So I went there and asked the man if they could do that for me. And he looked at me and said, 'Well, you're so thin that first of all we'd have to rub you down with ten pounds of pork fat to make sure you'd burn properly, and secondly it would be particularly expensive for you.' 'For me? Why?' I asked. 'Well, you see, we'd have to install a new grate in the furnace because you'd just keep falling through the one we have now.'

But even so, my skinniness has saved my life, like the time when I was in Africa with the cannibals and they captured me and wanted to roast me. So they made a big fire and got me undressed and when they saw me without any clothes on, they all took fright and ran away and so my life was saved.

\section{Physical peculiarity, fools and license}

The Encyclopedia of 20th Century American Humor contains an entry on 'body humor' which argues that, 'Deformed bodies have long been associated with humor as shown by European customs in the Middle Ages of 
using dwarves or hunchbacks as court jesters, clowns and fools' (Nilson and Nilson 2000: 53). This is just the little toe of a significant body of thought which connects physical abnormality with the role of the fool. Orrin E. Klapp's 1949 essay, 'The Fool as a social type', argues that:

The antics of the fool, his ugliness, gracelessness, senselessness, or possible deformity of body represent departures from corresponding group norms of propriety. The fool is the antithesis of decorum, beauty, grace, intelligence, strength, and other virtues embodied in heroes; and, therefore, as a type is antiheroic ... Any person who departs markedly from group norms of appearance is easily cast in the role of the fool.

(Klapp 1949: 157-158)

Similarly, Lawrence E. Mintz argues that modern comic performance can be traced back to 'the cruel but natural practice of ridiculing physical and mental defectives', says that the comedian represents the 'negative exemplar' who allows us to laugh 'at him', and that he enacts 'socially unacceptable traits' which are 'to be ridiculed, laughed at, repudiated, and, finally, symbolically "punished"' (Mintz 1985: 74).

This line of reasoning relates to the more general theory that comedians appeal to audiences by making them feel superior. As Clive Barker puts it, 'The craft of comedy relies to a high degree upon raising the personal and social tone of the audience to a sense of superiority over what is happening on the stage' (Barker 1978: 8-9).

The logic of this would suggest that, by exploiting his unusual skinniness, Valentin was allowing the audience to laugh at him by making himself seem deformed and inferior. Robert Eben Sackett argues that it was precisely this kind of audience-performer relationship to which Valentin owed his success:

$[\mathrm{H}] \mathrm{e}$ made a career out of representing chaos for those in his audience, and whether he was aware of it or not, thereby gave them feelings of superiority. . . . Worried that they were caught on a ladder of social decline, it reassured them to see Valentin on a much lower rung. . . By laughing, they 'punished' Valentin for his failures; grateful for the chance to do so, they rewarded him by coming again and again to watch him fail.

(Sackett 1982: 10)

The idea, then, is that Valentin's physical peculiarity would have been seen negatively, representing his role as a marginal outsider figure, to be scorned and laughed at, thus reinforcing the social values from which he deviated: order, authority, personal success.

However, this would be to ignore the flip side of theories about the physically abnormal fool figure, which Orrin E. Klapp describes as, 'low, low, ridiculed, tolerated and licensed' (Klapp 1949: 161). The idea of licence is crucial. The physically unusual comedian has the licence to express 
unconventional or socially unacceptable views, and these are not necessarily to be scorned or rejected. David Marc argues that by making jokes about his own fatness, the modern American stand-up comedian Louie Anderson 'demonstrates a powerful mastery over social convention by actively calling attention to his presumably deviant and deficient condition.' He continues:

Such a personality seems to know no fear of humiliation and thus appears to be dangerously outside the boundaries of social control . . . he indicates to the audience that he is a psychological daredevil capable of saying things that most of them would not consider saying in public.

(Marc 1989: 18)

Similarly, Mintz argues that when we 'identify with [a comedian's] expression or behaviour, secretly recognize it as reflecting natural tendencies in human activity if not socially approved ones, or publicly affirm it under the guise of "mere comedy," or "just kidding," he can become our comic spokesman...he serves as a shaman, leading us in a celebration of a community of shared culture, of homogeneous understanding and expectation.' (Mintz 1985: 74)

This interpretation allows us to see Valentin as a more assertive, subversive figure, a positive image of the downtrodden poor, skinny man, hitting back at authority with his unconventional approach to language and logic. A more subversive Valentin makes sense of the great admiration Brecht had for him.

\section{Physical peculiarity and comic self-discovery}

What makes Ich bin ein armer, magerer Mann such an important piece is that it was a key element in Valentin's comic breakthrough. A crucial aspect in the career of any comedian who works directly to an audience (whether a Volksänger like Valentin, or a modern stand-up comedian) is what is often referred to as 'finding the voice' (Double 2005: 87-89). The comic must find aspects of his or her own personality to focus on or exaggerate in order to bring to life a unique stage persona which an audience can recognise and relate to. Marc argues that because 'self is text to a much greater degree than for the dramatic comedian':

[f]atness, skinniness, shortness, tallness, beauty, ugliness, race, class, ethnicity, and/or whatever other visible or audible baggage the comedian carries in life is not merely fair game for exploitation on the stage but a textual feature of the act that demands use - or requires avoidance.

(Marc 1989: 18)

As Tony Allen points out, finding the voice is not necessarily the result of a deliberate, gradual process: 'Many successful comedians can remember a moment of enlightenment when they discovered the key to their comic attitude and like all personal quests, the Holy Grail is just as likely to be stumbled upon accidentally as it is by dogged experiment' (Allen 2002: 37). 
In Valentin's case, the 'Holy Grail' was not stumbled on by accident or dogged experiment, but arrived at with the help of Greiner, who encouraged him 'to compose and perform his couplets and monologues in a way that humorously drew attention to his stick-thin physique. Valentin immediately grasped this idea. From now on his skinny body would become a highly significant element of his comic performance' (Schulte 1982: 29).

This is by no means the only example of a comedian being helped by a collaborator to exploit his or her physicality as an aid to comic self-discovery. In 1953, for example, the great Italian comedian Dario Fo worked with Jacques Lecoq on the revue Il ditto nell'occhio (A Finger in the Eye), and it was Lecoq who trained him to make a virtue of his 'long arms and legs, uncoordinated body and flat feet', rather than hiding them (Mitchell 1984: 40).

Clearly, skinniness was absolutely central to Valentin's comic identity. Clive Barker argues that there is an important distinction to be drawn between the image and persona of the popular entertainer, persona being the identity adopted during performance, and image being 'the residual memory of a performer outside of the performance' (Barker 1978: 7). Image is used to market the performer's work, and, as such, it reflects key qualities of the persona. Examination of Valentin's image, as displayed in photographs and drawings used for publicity, shows that his skinniness is frequently emphasised. Costumes are tight fitting, the spindliness of his legs exaggerated by tights and oversized boots. His overall skinniness is often further exaggerated by the use of a long prosthetic nose.

\section{Superiority versus acceptance}

The main problem with the idea of comedian as negative exemplar to be laughed at and symbolically punished is that it sits uneasily with the essential dynamics of direct-to-audience live comedy. The concept of being laughed at implies that the laughter is unsolicited, and that its target does not consent to it. Clearly, this does not fit the context of professional comedy, where laughter is desired, consented to and worked at. Laughter is a sign, not of rejection but of approval, and this is confirmed by the applause which accompanies the particularly successful gags and the end of the act. Symbolic punishment for the live comedian comes in the form of hostile heckling, booing or indeed a lack of laughter. As Marc puts it, 'The comedian confronts the audience with his or her personality and wins celebration - the highest form of acceptance - or is scorned and rebuffed as a pitiable outsider' (Marc 1989: 12).

Even low status comedians, who play on being downtrodden or inept, simultaneously play a higher status role through the control they show in winning the desired responses from the audience. Indeed, such low status comedians as Norman Wisdom and Lee Evans also tangibly command audience respect through their demonstration of musical and physical skills.

Comedians tend to believe that it is not scorn but affection that characterises the feelings audiences have for them. Milton Berle, for example, has argued, 'The first thing is that an audience, I believe, has to like you, 
before they laugh at you.' Similarly, Woody Allen says, '[W]hat audiences want is intimacy with the person. They want to like the person and find the person funny as a funny human being. The biggest trap that comedians fall into is trying to get by on material.' (quoted in Double 2005: 61).

In some cases, this affection can be partly rooted in the comedian's physicality. As Double has previously argued, audiences can be 'irrationally drawn to' a comedian's 'voice, face, body, mannerisms or posture'. Evidence for this includes the luxuriant language which is often used to describe comedians' physicality (Double 2005: 63-66). In Valentin's case, there is no shortage of this kind of description. Kurt Tucholsky, the satirist and writer of cabaret songs, described him as: A stick-thin, gangly fellow with spindly, pointy Don Quixote legs, sharp, knobbly knees, a little hole in his trousers and a shiny, threadbare suit. The little hole in his trousers - he would manically scratch all around it' (Schulte 1984: 71). Likewise Wilhelm Haustenstein: 'He would stand and stumble in his total misery: endlessly long, all his proportions stretched this way and that way, as thin as a beanpole, as if he was in the middle of being overstretched on the rack, with a Don Quixote seriousness, a self-consumed comedian, declaring his melancholy' (Hausenstein 1958: 8-9).

Crucially, the moment Valentin began to emphasise his emaciated physicality was the very moment he gained the acceptance of the audience. Rather than being scorned as an outsider for his skinniness, he was being accepted in spite of it. Indeed, despite presenting himself as a poor skinny man who has been treated so badly by mother nature, the routine sees him triumph as much as he suffers: his father is proud of him; his size allows him to avoid being taken into the army (surely a benefit for an anti-militarist like Valentin); and the routine ends with a farcical episode where he avoids being eaten by cannibals because they take fright when they see what he looks like naked.

\section{Works cited}

Allen, Tony (2002), Attitude: Wanna Make Something Of It?, Glastonbury: Gothic Image.

Barker, Clive (1978), 'The “image” in show business', Theatre Quarterly, VIII: 29, pp. $7-11$.

Brecht, Bertolt (1965), The Messingkauf Dialogues (trans. John Willett), London: Methuen.

Double, Oliver (2005), Getting the Joke: The Inner Workings of Stand-Up Comedy, London: Methuen.

Ewen, Frederic (1970), Brecht: His Life, His Times, His Art, London: Calder and Boyars. Hausenstein, Wilhelm (1958), Die Masken des Komikers Karl Valentin, Freiburg: Herder. Hayman, Ronald (1983), Brecht: A Biography, London: Weidenfeld \& Nicolson.

Klapp, Orrin E. (1949), 'The fool as a social type', American Journal of Sociology, 55: 2, pp. 157-162.

Marc, David (1989), Comic Visions: Television Comedy and American Culture, Boston: Unwin Hyman.

Mintz, Lawrence E. (1985), 'Standup comedy as social and cultural mediation', American Quarterly, 37: 1, pp. 71-80. 
Mitchell, Tony (1984), Dario Fo: People's Court Jester, London and New York: Methuen.

Nilson, Alleen Pace and Nilson, Don L. F. (eds.) (2000), Encyclopedia of 20th Century American Humor, Phoenix, Arizona: Oryx Press.

Sackett, Robert Eben (1982), Popular Entertainment, Class, and Politics in Munich, 1900-1923, Cambridge, Mass.: Harvard University Press.

Schulte, Michael (1982), Karl Valentin: Eine Biographie, Hamburg: Hoffmann und Campe.

(ed.) (1984), Das Valentin Buch, Munich: Piper.

Valentin, Bertl (1971), “Du bleibst da, und zwar sofort!»: Mein Vater Karl Valentin, Munich: Piper.

\section{Suggested citation}

Double, O., \& Wilson, M. (2008), “I am a Poor, Skinny Man”: Persona and physicality in the work of Karl Valentin', Studies in Theatre and Performance 28: 3, pp. 213-221, doi: 10.1386/stap.28.3.213/1

\section{Contributor details}

Oliver Double is a Senior Lecturer in Drama at the University of Kent and a former professional comedian. His publications include Stand-Up! On Being a Comedian (1997), and Getting the Joke: The Inner Workings of Stand-Up Comedy (2005). A DVD of Saint Pancreas, a stand-up show he wrote and performed as part of a Practice-asResearch project, is available via the University of Kent website (http://www.kent. ac.uk/sdfva/drama/staff/odouble/stpancras.html).

E-mail: o.j.double@kent.ac.uk

Michael Wilson is Professor of Drama at the University of Glamorgan and a former professional storyteller. His publications include Storytelling and Theatre: Contemporary Storytellers and their Art (2006) and (with Richard Hand) Grand-Guignol: French Theatre of Horror (2002) and London's Grand-Guignol (2007).

E-mail: mwilson@glam.ac.uk 